\title{
Upaya meningkatkan minat dan hasil belajar PPKn melalui card sort
}

\author{
Moch. Shidiq ${ }^{\mathrm{a}, 1^{*}}$ \\ a SMP Negeri 6 Klaten \\ ${ }^{1}$ mochshidiq933@gmail.com \\ * korespondensi penulis
}

\begin{abstract}
ABSTRAK
Rumusan masalah dalam penelitian ini adalah apakah melalui model pembelajaran card sort dapat meningkatkan minat dan hasil belajar PPKn materi Memahami Kedudukan dan Fungsi Pancasila di kelas VIIIG SMP Negeri 6 Klaten Tahun Pelajaran 2019/2020?. Tujuan penelitian ini adalah: meningkatkan minat dan hasil belajar Pendidikan Pancasila dan Kewarganageraan (PPKn) memahami kedudukan dan fungsi Pancasila siswa kelas VIIIG SMP Negeri 6 Klaten tahun pelajaran 2015/2016 dengan metode pembelajaran Card Sort. Penelitian tindakan kelas ini dilakukan dalam dua siklus, masing-masing siklus meliputi: perencanaan, pelaksanaan tindakan, pengamatan dan refleksi. Pemanfaatan Pembelajaran dengan model pembelajaran Card Sort dapat meningkatkan minat dan hasil belajar siswa kelas VIII G SMP Negeri 6 Klaten pada semester 1 tahun pelajaran 2019/2020 dalam materi mamahami kedudukan dan Fungsi Panacasila. Minat belajar siswa meningkat, pada saat pra siklus hanya $34 \%$ meningkat menjadi $66 \%$ pada siklus I, dan meningkat lagi menjadi $90 \%$ pada akhir siklus II. Rata-rata nilai meningkat dari 52,93 (pra siklus) menjadi 75,17 pada siklus I dan meningkat lagi menjadi 83,62 pada siklus II. Prosentase ketuntasan hasil belajar juga mengalami peningkatan. Dari $10 \%$ pada pra siklus menjadi $45 \%$ pada siklus I dan meningkat lagi menjadi $93 \%$ pada siklus II.
\end{abstract}

Kata kunci: minat, hasil belajar, card sort

\section{ABSTRAK}

The formulation of the problem in this study is whether through the Card Sort learning model can increase interest and learning outcomes of PPKn material Understanding the Position and Function of Pancasila in class VIIIG SMP Negeri 6 Klaten Academic Year 2019/2020? The objectives of this research are: to increase interest and learning outcomes of Pancasila and Citizenship Education (PPKn) to understand the position and function of Pancasila in class VIIIG students of SMP Negeri 6 Klaten in the 2015/2016 academic year using the Card Sort learning method. This classroom action research was conducted in two cycles, each of which included: planning, implementing the action, observing and reflecting. The use of learning with the Card Sort learning model can increase interest and learning outcomes of class VIII G SMP Negeri 6 Klaten in semester 1 of the 2019/2020 academic year in understanding the position and function of Panacasila. Student interest in learning increased, at the time of the pre-cycle only 34\% increased to $66 \%$ in cycle I, and increased again to $90 \%$ at the end of cycle II. The average value increased from 52.93 (pre-cycle) to 75.17 in the first cycle and increased again to 83.62 in the second cycle. The percentage of completeness of learning outcomes has also increased. From $10 \%$ in pre cycle to $45 \%$ in cycle I and increase again to $93 \%$ in cycle II.

Keywords: interest, learning outcomes, card sort

Copyright (C2020 Universitas Ahmad Dahlan, All Right Reserved

\section{PENDAHULUAN}

Model Pembelajaran dengan Kurikulum Tingkat Satuan Pendidikan (KTSP) berstandar Kompetensi Lulusan (SKL) dan Standar Isi (SI) adalah mengacu pada pembelajaran kreatif, siswa lebih aktif dalam pembelajaran sedangkan guru bertindak sebagai motivator dan fasilitator. Artinya dalam pembelajaran guru mendorong siswa untuk kreatif dalam pembelajaran dan guru menginformasikan materi pembelajaran, siswa diberi kesempatan untuk mengeksploitasikan (menggali) materi yang sedang dipelajari. Dengan demikian model pembelajaran konvensional, dimana guru mendominasi dalam pembelajaran harus sudah ditinggalkan. Oleh sebab itu guru harus dapat menciptakan suasana belajar yang menyenangkan sehingga dapat menjadikan proses pembelajaran lebih efektif dan dapat mencapai hasil belajar yang memuaskan. Untuk itu penggunaan model pembelajaran yang kooperatif sangat diperlukan. Selain itu pemilihan dan penyajian media yang tepat dalam proses pembelajaran dapat menarik perhatian siswa dan juga membantu dalam mempermudah pemahaman tentang materi pelajaran yang disampaikan, sehingga berdampak pada peningkatan minat dan prestasi belajar.

Berdasarkan pengamatan peneliti, hasil ulangan harian memahami kedudukan dan fungsi Pancasila menunjukkan rata-rata nilai yang 
diperoleh masih berada di bawah KKN yaitu 52,93. Dari sebanyak 29 siswa baru 3 siswa (10\%) yang telah tuntas, sedangkan yang 26 siswa $(90 \%)$ belum tuntas. KKM PPKn di SMP Negeri 6 Klaten Tahun Pelajaran 2019/2020 adalah 78.

Berdasarkan dari masalah tersebut di atas, peneliti mengidentifikasi penyebab kegagalan siswa dalam belajar memahami kedudukan dan fungsi Pancasila yaitu: rendahnya perhatian siswa dalam mengikuti proses pembelajaran, kurangnya minat siswa dalam mempelajari memahami kedudukan dan fungsi Pancasila, dengan proses pembelajaran yang monoton dan membosankan.

Untuk menciptakan dan menumbuhkan minat belajar siswa dan agar siswa lebih tertarik pada materi, tentunya guru dituntut untuk mampu menciptakan suatu kondisi pembelajaran yang menyenangkan dan mampu merancang model pembelajaran yang lebih tepat serta penerapan media pembelajaran yang variatif. Dengan penggunaan model pembelajaran dan media yang variatif yang tepat siswa akan memperoleh gambaran yang jelas tentang proklamasi kemerdekaan, sehingga proses pembelajaran menjadi lebih menarik perhatian siswa, menumbuhkan semangat belajar dan antusiasme dalam belajar.

Rumusan masalah dalam penelitian ini adalah: 1) Apakah melalui model pembelajaran Card Sort dapat meningkatkan minat belajar PPKn memahami kedudukan dan fungsi Pancasila kelas VIIIG SMP Negeri 6 Klaten Tahun Pelajaran 2019/2020?; dan 2) Apakah melalui model pembelajaran Card Sort dapat meningkatkan hasil belajar PPKn memahami kedudukan dan fungsi Pancasila di kelas VIIIG SMP Negeri 6 Klaten Tahun Pelajaran 2019/2020?

Tujuan penelitian ini adalah untuk meningkatkan minat belajar PPKn memahami kedudukan dan fungsi Pancasila siswa kelas VIIIG SMP Negeri 6 Klaten dengan metode pembelajaran Card Sort. Tujuan kedua adalah ntuk meningkatkan hasil belajar PKn memahami kedudukan dan fungsi Pancasila siswa kelas VIIIG SMP Negeri 6 Klaten dengan metode pembelajaran Card Sort.

Penelitian ini diharapkan dapat memberikan manfaat: 1) siswa lebih antusias dan leluasa berpendapat sehingga minat belajar lebih maksimal; 2) memupuk dan meningkatkan keterlibatan, kegairahan, ketertarikan, kenyamanan, kesenangan dalam diri siswa untuk mengikuti proses pembelajaran di kelas; 3) memberikan wawasan bagi guru tentang model pembelajaran Card Sort (menyortir kartu); dan 4) Memberikan sumbangan positif dalam rangka meningkatkan mutu proses pembelajaran PPKn khususnya, dan mata pelajaran yang lain umumnya di SMP Negeri 6 Klaten.

\section{KERANGKA TEORETIS DAN HIPOTESIS TINDAKAN}

\section{Minat belajar}

Minat atau kesenangan belajar siswa merupakan suatu kondisi psikologis dalam diri siswa yang mampu mempengaruhi siswa dalam belajar. Minat adalah suatu rasa lebih suka dan rasa ketertarikan pada sesuatu hal atau aktivitas, tanpa ada yang menyuruh (Slameto, 2013, hal. 180). Minat adalah hubungan antara diri sendiri dengan sesuatu di luar diri. Semakin kuat hubungan tersebut, maka semakin kuat/besar minatnya. Menurut Sudarsono (2016, hal. 28) menyatakan bahwa minat merupakan sikap ketertarikan atau sepenuhnya terlibat dengan suatu kegiatan karena menyadarinya pentingnya atau bernilainya kegiatan tersebut. Minat yang ada pada diri seseorang akan memberikan gambaran dalam aktivitas untuk mencapai tujuan.

Di dalam belajar banyak siswa yang kurang berminat dan yang berminat terhadap pelajaran termasuk didalamnya adalah aktivitas praktek maupun teori untuk mencapai suatu tujuannya. Dengan diketahuinya minat seseorang akan dapat menentukan aktivitas apa saja yang dipilihnya dan akan melakukannya dengan senang hati. Dari beberapa teori di atas dapat disimpulkan minat belajar adalah kecenderungan seseorang yang berasal dari luar maupun dalam sanubari yang mendorongnya untuk merasa tertarik terhadap suatu hal sehingga mengarahkan perbuatannya kepada suatu hal tersebut dan menimbulkan perasaan senang.

Dalam penelitian ini minat belajar yang dimaksud adalah rasa senang, rasa ketertarikan, kemauan siswa untuk mengerjakan tugas (perhatian siswa), dan keterlibatan siswa dalam kegiatan pembelajaran di kelas khususnya pada memahami kedudukan dan fungsi Pancasila.

\section{Hasil belajar}

Sukmadinata (2012) menyatakan bahwa hasil belajar atau achievement merupakan realisasi atau pemekaran dari kecakapan-kecakapan potensial atau kapasitas yang dimiliki seseorang. Penguasaan hasil belajar oleh seseoang dapat dilihat dari perilakunya, baik perilaku dalam bentuk penguasaan pengetahuan, keterampilan berpikir maupun keterampilan motorik. Hampir sebagian besar dari kegiatan atau perilaku yang 
dapat diperlihatkan seseorang merupakan hasil belajar.

Menurut Surakhmad (2004, hal. 25) hasil belajar siswa bagi kebanyakan orang berarti ulangan, ujian atau tes. Maksud ulangan tersebut ialah untuk memperoleh suatu indek dalam menentukan keberhasilan siswa.

Menurut Sudjana (2009, hal. 162) keberhasilan belajar dipengaruhi oleh faktorfaktor: 1) Faktor-faktor yang ada dalam diri individu, mencakup aspek jasmaniah yang meliputi kondisi dan kesehatan jasmani, sedangkan aspek rohaniah atau psikis menyangkut kesehatan psikis, kemampuan intelektual, sosial, psikomotor, serta kondisi afektif individu; 2) Faktor lingkungan antara lain a) faktor keluarga: keadaan rumah, ruang tempat belajar, sarana belajar, suasana dalam rumah dan lingkungannya; b) sekolah: lingkungan sekolah, sarana dan prasarana belajar yang ada, sumber-sumber belajar, media belajar, hubungan dengan temanteman, guru dan staf; c) masyarakat: latar belakang pendidikan masyarakat memberikan pengaruh terhadap individu berada.

Dari definisi di atas, maka dapat diambil kesimpulan bahwa hasil belajar adalah prestasi belajar yang dicapai siswa dalam proses kegiatan belajar mengajar dengan membawa suatu perubahan dan pembentukan tingkah laku seseorang.

\section{Model pembelajaran Card Sort}

Menurut Joyce \& Weil (2000) dalam Mulyani Sumantri, dkk (Sumantri \& Permana, 2001, hal. 42) model pembelajaran adalah kerangka konseptual yang melukiskan prosedur yang sistematis dalam mengorganisasikan pengalaman belajar untuk mencapai tujuan pembelajaran tertentu, dan memiliki fungsi sebagai pedoman bagi para perancang pembelajaran dan para pengajar dalam merencanakan dan melaksanakan aktifitas belajar mengajar.

Sedangkan Arends (Trianto, 2007, hal. 51) menyatakan bahwa model pembelajaran mengacu pada pendekatan yang akan digunakan, termasuk di dalamnya tujuan-tujuan pembelajaran, tahaptahap dalam kegiatan pembelajaran, lingkungan pembelajaran, dan pengelolaan kelas. Model pembelajaran dapat didefinisikan sebagai kerangka konseptual yang melukiskan prosedur sistematis dalam mengorganisasikan pengalaman belajar untuk mencapai tujuan belajar.

Model pembelajaran card sort merupakan kegiatan kolaboratif yang bisa digunakan untuk mengajarkan konsep penggolongan, sifat, fakta tentang suatu obyek, atau mengulang informasi. Gerakan fisik yang dilakukan siswa dapat membantu untuk memberi energi kepada kelas yang telah letih. Model pembelajaran ini mengajak siswa untuk belajar aktif dan bertujuan agar siswa mempunyai jiwa kemandirian dalam belajar serta menumbuhkan daya kreativitas. Model pembelajaran card sort atau menyortir kartu adalah model pembelajaran yang sangat sederhana yang terdiri dari kartu induk dan kartu rincian yang berisikan materi yang akan disampaikan pendidik kepada siswa.

Hipotesis tindakan sebagai berikut: 1) Melalui model pembelajaran card sort dapat meningkatkan minat belajar PKn memahami kedudukan dan fungsi Pancasila di kelas VIIIG SMP Negeri 6 Klaten tahun pelajaran 2019/2020; dan 2) Melalui model pembelajaran card sort dapat meningkatkan hasil belajar PKn memahami kedudukan dan fungsi Pancasila di kelas VIIIG SMP Negeri 6 Klaten tahun pelajaran 2019/2020.

\section{METODE}

Penelitian ini dilakukan selama 3 bulan yaitu mulai Oktober sampai Desember 2015, dalam bentuk penelitian tindakan kelas. Tempat penelitian tindakan kelas ini adalah di SMP Negeri 6 Klaten, di kelas VIII G pada semester I tahun pelajaran 2019/2020. Subyek Penelitian tindakan kelas ini adalah siswa kelas VIIIG SMP Negeri 6 Klaten dengan jumlah siswa sebanyak 29, yang terdiri dari 14 siswa laki-laki dan 15 siswa perempuan. Sumber data dalam penelitian ini adalah arsip/dokumen, hasil observasi minat belajar siswa dan aktifitas guru dalam proses pembelajaran, hasil tes akhir siklus (nilai ulangan harian) dan foto. Teknik Pengumpulan Data dalam penelitian ini adalah: 1) Observasi minat siswa dan aktifitas guru; 2) Tes; dan 3) Studi dokumentasi.

Teknik analisis data yang digunakan dalam penelitian ini adalah analisis data yang bersifat kualitatif dan kuantitatif. Indikator kinerjanya adalah: 1) Minimal $75 \%$ siswa nilai minat belajarnya baik; 2) Rata-rata nilai ulangan harian meningkat; dan 3) Siswa nilai ulangan hariannya minimal mencapai KKM, yaitu 78, secara klasikal $90 \%$.

Penelitian Tindakan Kelas ini dilakukan dalam 2 siklus, dengan tahapan setiap siklusnya sebagai berikut: 1) planning (rencana) yang meliputi kegiatan: penyusunan rencana pelaksanaan pembelajaran (RPP) dengan pembuatan media card, menyiapkan kartu induk dan kartu rincian untuk card sort (diskusi kelompok), penyusunan lembar observasi, dan alat 
evaluasi; 2) Acting (pelaksanaan) yaitu melaksanakan skenario pembelajaran dengan menggunakan model pembelajaran card sort yaitu siswa dalam kelompok diminta berdiskusi dan menyortir kartu rincian yang kemudian dipasangkan dengan kartu induk lalu mengisi lembar deskripsi dan mempresentasikan hasilnya; 3) observing (observasi), pada tahap ini dikumpulkan data dan informasi dari berbagai sumber untuk mengetahui seberapa jauh keberhasilan dari tindakan yang telah dilakukan. Data tentang minat belajar siswa diperoleh dari lembar pengamatan (observasi) dalam proses pembelajaran memahami kedudukan dan fungsi Pancasila. Sedangkan untuk memperoleh gambaran seberapa jauh memahami kedudukan dan fungsi Pancasila yang mampu diserap siswa dan seberapa besar tingkat ketuntasan belajar siswa dengan menggunakan teknik tes tertulis sehingga diperoleh data kuantitatif (angka); dan 4) reflecting (refleksi), yaitu melakukan kegiatan untuk mengulas secara kritis dan mengetahui perubahanperubahan, hal-hal yang perlu diperbaiki juga evaluasi hasil penelitian sebagai dasar untuk menyusun perencanaan siklus berikutnya dan untuk pengambilan keputusan.

\section{HASIL DAN PEMBAHASAN}

\section{Deskripsi siklus I}

\section{Planning (Perencanaan)}

Kegiatan yang dilakukan pada tahap ini adalah Menyusun RPP sesuai dengan tindakan yang akan dilakukan, menyusun media yang diperlukan dalam penelitian. membuat lembar pengamatan (observasi) untuk melihat suasana pembelajaran (minat siswa) selama proses pembelajaran, membuat rancangan analisis ulangan harian pada siklus ini, untuk melihat peningkatan penguasaan memahami kedudukan dan fungsi Pancasila dengan model pembelajaran card sort, membuat LKS (dikripsi card sort) untuk diskusi siswa.

\section{Acting (pelaksanaan)}

Pembelajaran siklus I dilaksanakan pada hari Senin, tanggal 4 November 2019 jam 1-2 dan hari Senin tanggal 11 November 2019 jam 1-2. Dalam kegiatan ini guru menyiapkan bahan dan alat card sort berupa media kartu yang terdiri dari kartu induk dan kartu rincian untuk siswa. Pada awal pelajaran guru membuka pelajaran dengan memeriksa kesiapan siswa, menjelaskan judul dan tujuan pembelajaran dan mengajukan pertanyaan pendahuluan yang ada kaitannya dengan materi yang akan diajarkan. Guru membagi siswa dalam 5 kelompok, tiap kelompok terdiri dari 6 siswa.
Setiap kelompok diberi tugas untuk diskusi menyatukan kartu induk dengan kartu rincian. Guru mengamati siswa dalam berdiskusi dan sedikit membimbing. Guru dan siswa membuat simpulan. Dan di akhir pembelajaran guru mengadakan tes formatif.

\section{Observing (Observasi)}

Pengamatan dilakukan selama proses pembelajaran berlangsung. Data yang dihimpun dari hasil pengamatan aalah sebagai berikut: Dari hasil pengamatan pada siklus I diperoleh siswa nilai minatnya baik 19 siswa (66\%). Sedangkan hasil ulangan harian diperoleh rata-rata 75,17 , jumlah siswa yang telah tuntas sebanyak 13 (45\%) dan jumlah siswa yang belum tuntas sebanyak 16 (55\%). Hasil tersebut memang sudah ada kemajuan dari pra siklus, walaupun rata-rata kelas belum mencapai KKM (78). Tetapi jumlah siswa yang sudah mencapai KKM baru 13 (45\%), sehingga penelitian ini perlu dilanjutkan pada siklus ke II.

\section{Reflekting (Refleksi)}

Berdasarkan hasil observasi yang dilaksanakan selama proses pembelajaran dengan model pembelajaran Card sort melalui media kartu menunjukkan adanya peningkatan minat siswa dan juga berpengaruh terhadap peningkatan hasil belajar (ulangan/test). Namun waktu presentasi suara siswa kurang keras dan siswa tidak berani menatap peserta lainnya sehingga terkesan kelihatan canggung karena belum terbiasa, Untuk itu pada siklus ke II peneliti akan menumbuhkan rasa percaya diri dan memperbaiki pembelajaran dengan mengoptimalkan bimbingan guru pada kelompok yang mengalami kesulitan. Waktu belum dapat digunakan secara efektif, karena masih banyak siswa yang tidak memperhatikan penjelasan guru, ada yang melamun, bermain sendiri, ngobrol dengan temannya. Pada waktu akan presentasi banyak siswa yang tidak mau menjadi juru bicara. Untuk itu pada siklus II guru harus memberikan motivasi kepada siswa agar berani menyampaikan pendapat. Di dalam kerja kelompok masih didominasi oleh beberapa siswa, sehingga kerja kelompok belum maksimal. Masih banyak siswa yang menggantungkan pada temannya yang pandai. Untuk itu, pada siklus II nanti jumlah anggota kelompok harus dikurangi dan menambah jumlah kelompok.

\section{Deskripsi siklus II}

\section{Planning (Perencanaan)}

Menyusun RPP sesuai dengan tindakan yang akan dilakukan, menyiapkan alat dan bahan (media) yang diperlukan dalam penelitian, membuat Iembar pengamatan (observasi) untuk 
melihat suasana pembelajaran (minat belajar siswa) selarna proses pembelajaran, membuat rancangan analisis ulangan harian pada siklus II, membuat LKS (lembar deskripsi) untuk diskusi siswa.

\section{Acting (pelaksanaan)}

Proses ini dilaksanakan pada hari Senin tanggal 18 November 2019 Jam 1- 2 dan hari Senin tanggal 25 November 2019 jam 1-2. Guru menyiapkan media untuk pembelajaran. Pada awal pelajaran guru membuka pelajaran dengan memeriksa kesiapan peserta didik, menjelaskan judul dan tujuan pembelajaran dan mengajukan pertanyaan pendahuluan yang ada kaitannya dengan materi yang akan diajarkan dan materi sudah diajarkan. Guru membagi siswa dalam 7 kelompok, tiap kelompok terdiri dari 4 siswa dan 1 kelompok terdiri dari 5 siswa. Setiap kelompok diberi tugas untuk diskusi menyatukan kartu induk dengan kartu rincian. Guru dan observer membimbing siswa per kelompok dalam menyatukan kartu dan mendeskripsikan dalam lembar deskripsi. Guru meminta siswa untuk menukar hasil diskusinya dengan kelompok lain. Guru meminta siswa untuk mempelajari hasil diskusi kelompok lain. Guru menugaskan siswa untuk mempresentasikan hasil diskusi kelompok lain yang ditukar sebelumnya. Guru memberi rnotivasi siswa agar berani presentasi, guru menumbuhkan/menanamkan rasa percaya diri pada siswa yang presentasi. Di akhir pembelajaran, guru mengadakan ulangan (test) 2 .

\section{Observing (Observasi)}

Selama proses pembelajaran pada siklus II diperoleh siswa nilai minatnya baik meningkat yaitu 26 siswa (90\%). Dan hasil ulangan harian diperoleh rata-rata yang meningkat pula yaitu dari 75,17 menjadi 83,62 . Jumlah siswa yang telah tuntas sebanyak 27 (93\%) dan jumlah siswa yang belum tuntas sebanyak $2(7 \%)$.

\section{Reflekting (Refleksi)}

Berdasar hasil pengamatan, perhatian siswa lebih baik daripada siklus I. Jumlah siswa yang bergurau berkurang. Saat pembelajaran tampak lebih hidup, siswa tampak lebih senang dalam mengikuti proses pembelajaran karena ada unsur permainan. Waktu presentasi siswa sudah tidak canggung dan tampak percaya diri karena sudah terbiasa. Waktu sudah dapat digunakan secara efektif, terbukti semua kelompok dapat menyelesaikan tugas tepat waktu. Pada waktu akan presentasi siswa sudah tidak takut menjadi juru bicara ataupun moderator. Saat presentasi suara siswa sudah jelas dan siswa sudah berani menatap peserta presentasi. Ini berarti rasa percaya diri siswa sudah tumbuh. Guru sudah memberikan motivasi kepada siswa, sehingga siswa sudah tidak takut untuk melakukan presentasi. Guru dan observer sudah memberikan bimbingan per kelompok kepada siswa, sehingga kesulitan siswa per kelompok dapat langsung teratasi.

Setelah menyelesaikan tindakan pada siklus ke II diadakan analisis dan evaluasi data sebagai berikut: Nilai minat dari pra siklus, siklus I dan siklus II mengalami peningkatan. Secara rinci nilai minat belajar siswa selama penelitian dapat dilihat pada table berikut ini:

Tabel 1 Nilai minat belajar siswa

\begin{tabular}{l|l|l|l|l|l|l|l}
\hline \multirow{2}{*}{ No } & \multirow{2}{*}{ Kriteria } & \multicolumn{2}{l|}{ Pra Siklus } & Siklus 1 & \multicolumn{2}{l}{ Siklus 2 } \\
\cline { 3 - 8 } & & Jumlah & Presentase & Jumlah & Presentase & Jumlah & Presentase \\
\hline 1 & Sangat Baik & 3 & 10 & 4 & 14 & 4 & 14 \\
\hline 2 & Baik & 7 & 24 & 15 & 52 & 22 & 76 \\
\hline 3 & Cukup Baik & 7 & 24 & 5 & 17 & 3 & 10 \\
\hline 4 & Kurang Baik & 7 & 24 & 5 & 17 & & \\
\hline 5 & Sangat Kurang Baik & 5 & 17 & & & & \\
\hline & Jumlah & 29 & 100 & 29 & 100 & 29 & 100 \\
\hline
\end{tabular}

Selain itu rata-rata nilai ulangan harian dan ketuntasan belajar juga mengalami peningkatan dari pra siklus, siklus I dan siklus II, hal ini terlihat pada tabel berikut: 
Tabel 2 Rata-rata nilai ulangan harian ketuntasan belajar

\begin{tabular}{l|l|l|l|l}
\hline No & Uraian & Pra Siklus & Silkus 1 & Siklus 2 \\
\hline 1 & Rata-rata & 52,93 & 75,17 & 83,62 \\
\hline 2 & Nilai Tertinggi & 90 & 100 & 100 \\
\hline 3 & Nilai Terendah & 5 & 55 & 65 \\
\hline 4 & Mencapai KKM & 3 & 13 & 27 \\
\hline 5 & Presentase Tuntas & 10 & 45 & 93 \\
\hline
\end{tabular}

\section{Pembahasan}

Hasil analisa sebelum tindakan (pra siklus) dan setelah dilakukan tindakan siklus I dan siklus II dapat diketahui terjadi peningkatan minat belajar PPKn bagi siswa kelas VIII G SMP Negeri 6 Klaten. Yaitu dari $34 \%$ pada pra siklus meningkat menjadi $66 \%$ pada siklus I dan meningkat lagi menjadi $90 \%$ pada siklus II.

Selanjutnya hasil analisa sebelum dan setelah tindakan siklus I dan siklus II dapat diketahui terjadi peningkatan prestasi belajar melalui model pembelajaran card sort bagi siswa kelas VIIIG SMP Negeri 6 Klaten. Nilai rata-rata PKn sebelum menerapkan model pembelajaran card sort sebesar 52,93, meningkat pada siklus I yaitu 75,17 dan meningkat lagi pada akhir siklus II menjadi 83,62.

Hal ini sesuai dengan pandangan Arends (Trianto, 2007), model pembelajaran mengacu pada pendekatan yang akan digunakan, termasuk di dalamnya tujuan-tujuan pembelajaran, tahaptahap dalam kegiatan pembelajaran, lingkungan pembelajaran, dan pengelolaan kelas. Model Pembelajaran card sort merupakan kegiatan kolaboratif yang bisa digunakan untuk mengajarkan konsep penggolongan, sifat, fakta tentang suatu obyek, atau mengulang informasi. Gerakan fisik yang dilakukan siswa dapat membantu untuk memberi energi kepada kelas yang telah letih. Model pembelajaran ini mengajak siswa untuk belajar aktif dan bertujuan agar siswa mempunyai jiwa kemandirian dalam belajar serta menumbuhkan daya kreativitas.

\section{KESIMPULAN}

Kesimpulan yang dibuat dalam penelitian ini adalah sebagai berikut: 1) Pembelajaran dengan model pembelajaran card sort dapat meningkatkan minat siswa kelas VIIIG SMP Negeri 6 Klaten pada semester 1 tahun pelajaran 2019/2020 dalam memahami kedudukan dan Fungsi Pancasila. 2) Pembelajaran dengan model pembelajaran card sort dapat meningkatkan hasil belajar siswa kelas VIIIG SMP Negeri 6 Klaten pada semester 1 tahun pelajaran 2019/2020 dalam memahami kedudukan dan fungsi Pancasila.

\section{UCAPAN TERIMA KASIH}

Pada kesempatan yang baik ini, saya ucapkan terimakasih kepada: 1) Kepala Sekolah SMPN 6 Klaten, Drs. Eguh Setyo Surono, MM, yang telah memberikan izin penelitian, mendorong serta membimbing hingga terselesaikannya penelitian ini; 2) Dra. Sri Harpatmi, M.Pd, istriku tercinta yang telah memberikan semangat dan kasih sayang dari perencanaan hingga terselesaikannya penelitian sederhana ini; 3) Kabid Pendidikan Ketenaga Kerjaan, Dinas Pendidikan Klaten, $\mathrm{H}$ Wasana, S.Pd, M.Pd yang selalujadi kaonsultan, membimbing dan mengarahkan hingga terselesaikannya PTK ini; 4 \} Rekan-rekan guru SMPN 6 Klaten yang telah membantu segala sesuatu hingga selesai karya tulis sederhana ini.

\section{DAFTAR PUSTAKA}

Joyce, B., Weil, M., \& Calhoun, E. (2000). Model of teaching. Allyn and bacon a Pearson Education Company.

Slameto. (2013). Belajar \& faktor-faktor yang mempengaruhinya (Edisi Revi). Rineka Cipta.

Sudarsono, J. (2016). Sistem Pendidikan Nasional. Rineka Cipta.

Sudjana, N. (2009). Penilain Hasil Proses Belajar Mengajar. PT. Remaja Rosdakarya.

Sukmadinata, N. S. (2012). Metode penelitian pendidikan. PT. Remaja Rosdakarya.

Sumantri, M., \& Permana, J. (2001). Strategi Belajar Mengajar. CV Maulana.

Surakhmad, W. (2004). Pengantar interaksi mengajar-belajar dasar dan teknik metodologi pengajaran. Tarsito.

Trianto. (2007). Model-model Pembelajaran Inovatif Berorientasi Konstruktivistik. Pustaka Prestasi. 